\title{
Economic effectiveness of pike (Esox lucius L.) stocking based on the example of selected lakes in East European Plain with consideration of their natural conditons
}

\author{
Maciej Mickiewicz, Marek Trella
}

Received - 03 February 2019/Accepted - 03 September 2019. Published online: 30 September 2019; $\odot$ Inland Fisheries Institute in Olsztyn, Poland Citation: Mickiewicz M., Trella M. 2019 - Economic effectiveness of pike (Esox lucius L.) stocking based on the example of selected lakes in East European Plain with consideration of their natural conditons - Fish. Aquat. Life 27: 136-148.

\begin{abstract}
The aim of the study was to assess the economic effectiveness of pike (Esox lucius L.) stocking based on the value of fish caught with commercial fishing gears and the value of stocking material introduced into 44 lakes in the Ełk Lake District in northeastern Poland. The effectiveness of stocking is presented against the background of lake environmental conditions in the context of their natural potential for pike populations to inhabit and develop in them. The data analyzed regarded the size and value of catches and stocking from 1996-2017 that was obtained from an entity authorized to exploit fisheries. Information on selected lake morphometric, morphological, and environmental parameters was also obtained from this source. The value of pike catches in the analyzed period was characterized by a high, stabile level, and the stocking level increased. The indicator of the stocking economic effectiveness was at a high average annual level in excess of 3.9 PLN of catches per 1.0 PLN for stocking, but it decreased during the period analyzed. The high stocking effectiveness in the studied lakes was determined by, inter alia, natural conditions, stocking material quality, properly performed stocking, and efficient exploitation. However, it can be concluded that it is mainly stocking that maintains pike catches at a high, relatively stable level in the lakes analyzed. Additionally, new methods of pike population management are discussed, e.g., catch and release.
\end{abstract}

\footnotetext{
M. Mickiewicz, M. Trella [ $\left.\Xi^{\circ}\right]$

Department of Fisheries Bioeconomics, Inland Fisheries Institute in Olsztyn

ul. Oczapowskiego 10, 10-719 Olsztyn, Poland

e-mail:m.trella@infish.com.pl
}

Keywords: pike, stocking effectiveness, fisheries management, environment, lakes

\section{Introduction}

The role of pike in fisheries management has grown since the fisheries ownership transformation in Poland of the mid 1990s. This has been influenced by the significance of recreational fisheries and rising prices of glass eel, Anguilla anguilla (L.) (Wołos 2000, Mickiewicz 2012). The increasing importance of pike in Poland provided the impetus for undertaking studies of the economic (Mickiewicz 2013) and biological (Szczepkowski et al. 2012, 2015, 2016) effectiveness of stocking this species and also of methods for managing populations of this species (Zakęś et al. 2015, Czarkowski and Kapusta 2016). Pike currently dominates among the species that are stocked into lakes, rivers, and dam reservoirs in Poland (Mickiewicz and Wołos 2012, Mickiewicz and Trella 2016, 2017, Mickiewicz 2018a). Recreational fishers catch this species in large quantities (Arlinghaus et al. 2008), and in Poland mainly in lakes (Trella and Wołos 2015, Mickiewicz 2016), which was confirmed by studies of the 
preferences of lake recreational fishers (Wołos 1991, Bnińska and Wołos 2001).

The scientific literature on pike stocking contains reports on the successful effectiveness of this measure (Mann 1996, Wysujack et al. 2001, Sutela et al. 2004). With muskellunge (Esox masquinongy Mitchill) it was demonstrated that stocking with hatchlings was more economically effective than stocking with older material (Margenau 1992). However, there are also reports of ineffective results of stocking. Guillerault et al. (2018) demonstrated that pike originating from stocking survived two spawning seasons after which they dispersed in the river at distances of several kilometers. Additionally, the recreational catch index of pike originating from stocking was low (9.6\%), which suggests that the effectiveness of stocking was doubtful. Hühn et al. (2014) demonstrated that competition among fry reared in hatcheries and those from natural spawning was disadvantageous in that the reared fry outcompeted those from natural spawning. Pike stocking material has also been used regularly in biomanipulations applied to improve water quality by eliminating small carp species (Søndergaard et al. 1997, Skov et al. 2003, Skov and Nilsson 2007, Winfield 2015).

Pike was the principle species stocked in the lakes analyzed. During the period analyzed, this species was stocked into all of them. Data obtained from entities authorized to exploit fisheries indicated that in the lakes analyzed in 2017 the value of pike stocking was $75 \%$ of the value of all stocking performed. The weight of pike in the total weight of fish caught with commercial fishery gears was $26 \%$, and it occupied first position ahead of common bream, Abramis brama (L.), and vendace, Coregonus albula (L.). Recreational fishers also caught pike, and the mean annual share of it in the species structure of the total weight of recreational catches was $19 \%$, and it occupied third place following perch, Perca fluviatilis L. (24\%), and roach, Rutilus rutilus (L.) (22\%), in the 1998-2005 period. Based on just 110 recreational fisheries questionnaires collected on average annually in the 1998-2005 period, the weight of pike was estimated at over $1,000 \mathrm{~kg}_{\text {year }}{ }^{-1}$ (Mickiewicz 2010). Pike is also under pressure from great cormorants (Phalacrocorax carbo (L.)) and poachers (Mickiewicz 2016). In the Warmia and Mazury Voivodeship alone, where the analyzed lakes are located, great cormorants annually consumed pike, which had not yet spawned, that were of an average weight of 240-260 g. The value of these fish was estimated to be approximately 2.2 million PLN (Krzywosz et al. 2009).

The aim of this study was to estimate the economic effectiveness of pike stocking based on the value of fish caught with commercial fishery gears and also the value of the stocking material released into the 44 lakes analyzed. Basing the study on the criteria of the value of stocking and catches permitted avoiding the problem of the varied survival rates of different forms of stocking material (foraging hatchlings, summer and fall fry), and answering the fundamental question of whether the financial resources expended on pike stocking generated revenue. Pike stocking effectiveness is presented in light of the general analysis of the environmental conditions in the lakes analyzed in the context of their natural potential for pike populations to inhabit and develop in them.

\section{Material and methods}

According to the physiographic division of Europe, the lakes analyzed are located in the Ełk Lake District, which is part of the Masurian the Eastern Baltic Lake Districts and the Eastern European Plain. Administratively, the lakes are located in the Warmia and Mazury Voivodeship in northeastern Poland (Fig. 1). The Gospodarstwo Jeziorowe Sp. z o.o. (English Lake Fisheries Enterprise Ltd., hereinafter referred to as the LFE) in Ełk is the enterprise authorized to exploit the fisheries of the 44 lakes analyzed, which have a total area of 6005.20 ha. This enterprise has its own hatchery that produces foraging pike hatchlings and earthen ponds in which summer and fall fry are reared. All stocking material is produced by the LFE itself and is obtained from wild pike spawners caught in lakes. 


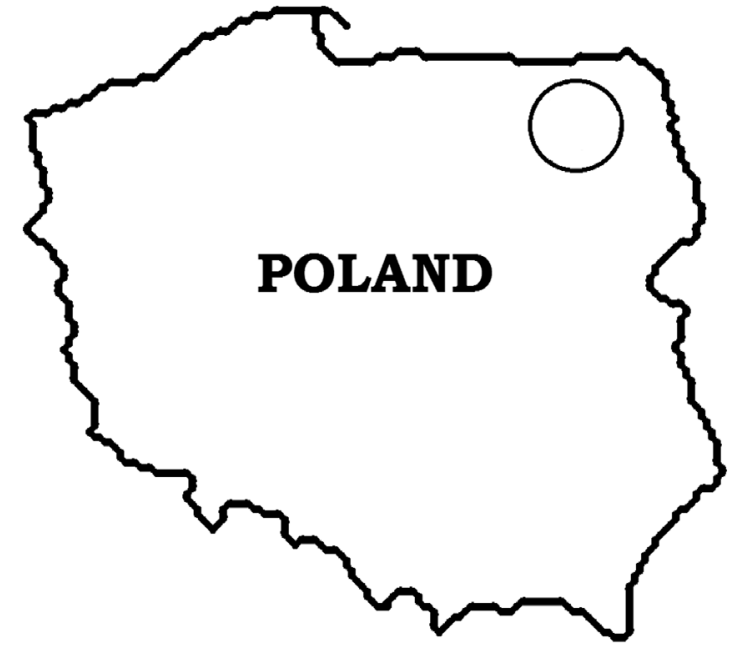

Fig. 1. Ełk Lake District.

The LFE conducts commercial and recreational fisheries in which catching fish with commercial fishery and recreational angling gears is equally important. According to their agreement with the State Treasury, the owner of the waters, the LFE is required to earmark annually for stocking at least $15 \%$ of the value of fish caught with commercial fishery gears. Details regarding the exploitation of lakes and the species structure and amount of stocking are found in commercial and recreational fishery management plans developed by the LFE. These are reviewed and approved by authorized scientific institutions in accordance with binding procedures in Poland. The LFE issues fishing permits for exploiting the lakes annually to 200-300 recreational fishers for the entire season, to 2,000-3,000 recreational fishers for periods of time (e.g., 14 days), and to 5,000-7,000 recreational fishers on a daily basis.

This study was based on materials obtained from the LFE and on the results of studies on the prices of fish and stocking material:

- information on arbitrarily selected morphological and environmental parameters of the 44 lakes studied, including surface area, maximum and mean depth, the shoreline development index, the share of bottom surface area covered by submerged vegetation, Secchi depth, and the depth to which oxygen content is sufficient for fish at the height of the summer stagnation period. This information was obtained from current fisheries management plans for the analyzed lakes;

- information on the size of commercial pike catches in the analyzed lakes and information on the quantity and types of pike stocking material released into the analyzed lakes in the 1996-2017 period;

- data on the wholesale price of commercial pike (12.91 PLN kg ${ }^{-1}$ ) and the prices of the most important forms of pike stocking material (foraging hatchlings - 21.31 PLN thou. ind. ${ }^{-1}$, summer fry - 111.27 PLN thou. ind.$^{-1}$, fall fry - 25.11 PLN $\mathrm{kg}^{-1}$ ) released by the entity authorized to exploit the fisheries in fishery district waters in 2017 (Mickiewicz 2018b).

The results presented in this study were obtained using the following calculation methods:

- the share (\%) of lake surface area in which one of the seven selected environmental factors favorable to pike was calculated, i.e., surface area up to 150 ha, maximum depth up to 12 $\mathrm{m}$, mean depth up to $4.5 \mathrm{~m}$, highly or very highly developed shoreline, share of bottom surface area covered by submerged vegetation exceeding 20\%, Secchi depth exceeding $1 \mathrm{~m}$, and the depth to which oxygen content is sufficient for fish at the height of the summer stagnation period of at least $5 \mathrm{~m}$. Next, the share (\%) of lake surface area was calculated in which four, five, and six of the seven environmental environmental factors that are favorable to pike occurred;

- the value of catches and stocking (PLN) was calculated by multiplying their sized by the mean national wholesale price of commercial pike and the mean national price of pike stocking material - foraging hatchlings, summer and fall fry;

- the values calculated are presented as indexes $\left(\mathrm{PLN} \mathrm{ha}^{-1}\right)$ in reference to the total surface area of the lakes analyzed (6005.20 ha). Catch yield is also presented as an index $\left(\mathrm{kg} \mathrm{ha}^{-1}\right)$. The mean annual values of all the sizes, values, 
and indexes were also calculated for the 1996-2017 period analyzed;

- three-year means were calculated from the annual values of commercial pike catches and then referenced to the relative annual value of stocking (PLN ha'). A two-year shift was applied with the assumption that the greatest effect of pike stocking is obtained two years following stocking and that is persists for the subsequent two years. Stocking conducted in 1996 corresponded to mean annual catches in 1998, 1999, 2000, etc. This is how the economic value of stocking index was calculated - the value (PLN ha ${ }^{-1}$ ) of pike catches per $1 \mathrm{PLN} \mathrm{ha}^{-1}$ of pike stocking. The mean annual stocking index was calculated for the indexes obtained for the 1998-2015 period;

- basic statistical parameters were used in the study such as percentages, medians, V\%, standard deviations (SD), and determination coefficients. Time series analysis was also applied with a degree of probability of $\mathrm{P} \leq$ 0.05 as the limit. A linear function was used to show trends in changes among the years analyzed;

- the study was based on the prices of commercial pike and stocking material released in 2017, and the values are in PLN (the weighted annual exchange rates in 2017 were 1 USD - 3.7777 PLN, 1 EUR - 4.2576 PLN, and 1 GBP - 4.601 PLN).

\section{Results and discussion}

The selected morphological and environmental factors of the lakes analyzed were varied (Table 1). Numerically, those with surface areas that did not exceed 150 ha dominated (34 lakes, 25\% of the total surface area). Maximum depth not exceeding $12.0 \mathrm{~m}$ was noted in 28 lakes, which was $32 \%$ of the total surface area of the lakes analyzed, while the mean depth (up to $4.5 \mathrm{~m}$ ) was noted in 27 lakes, which was
$38 \%$ of the total surface area of the lakes. Fourteen of the lakes had highly or very highly developed shorelines, which was $74 \%$ of the surface area of all the lakes, while 33 lakes (approximately 50\% of the total surface area) had rich submerged vegetation covering in excess of $20 \%$ of the bottom surface area. Thirty-four of the lakes had high water transparency (visibility exceeding $1 \mathrm{~m}$ as measured with a Secchi disc), which was $78 \%$ of the total water surface area analyzed. Oxygen content to a depth of at least $5 \mathrm{~m}$ that was sufficient for pike at the height of the summer stagnation period was noted nearly throughout the surface area analyzed (99\%) and in 42 lakes.

Based on the overall analysis of the indexes of the analyzed lakes, most of lakes were suitable for pike, at least in terms of the assumed values of at least one of the parameters analyzed; however, none of the lakes analyzed had acceptable values for all seven parameters. Fifteen lakes met the criteria for six of the indexes $(10 \%$ of the total surface area), ten lakes met the criteria for five indexes $(19 \%$ of the total surface area), and 11 lakes met the criteria of four indexes (23\% of the total surface area). Although six parameters met the criteria for pike, the one that was insufficient (e.g., water transparency) prevented the dynamic development of pike in the lake. On the other hand, the lack of one parameter meeting the criteria sufficient for pike (e.g., surface area, shoreline development index) did not necessarily interfere with the functioning of the populations. However, at least 36 lakes in which four, five, or six, of the parameters met the criteria for pike ( $52 \%$ of the surface area) one can certainly view these lakes, according to generally accepted standards, as suitable for pike even though pike was caught in all of the lakes.

Larsson et al. (2015) studied the conditions that affect pike spawning and larval development and ultimately its optimal reproduction. The occurrence of appropriate vegetation (sedges and grass tufts), in both wetlands, where pike spawn, and in water zones where juveniles develop (reeds) was significant. Depth (mean 20-50 cm) and the stability of water flow rates from wetlands were important as was 


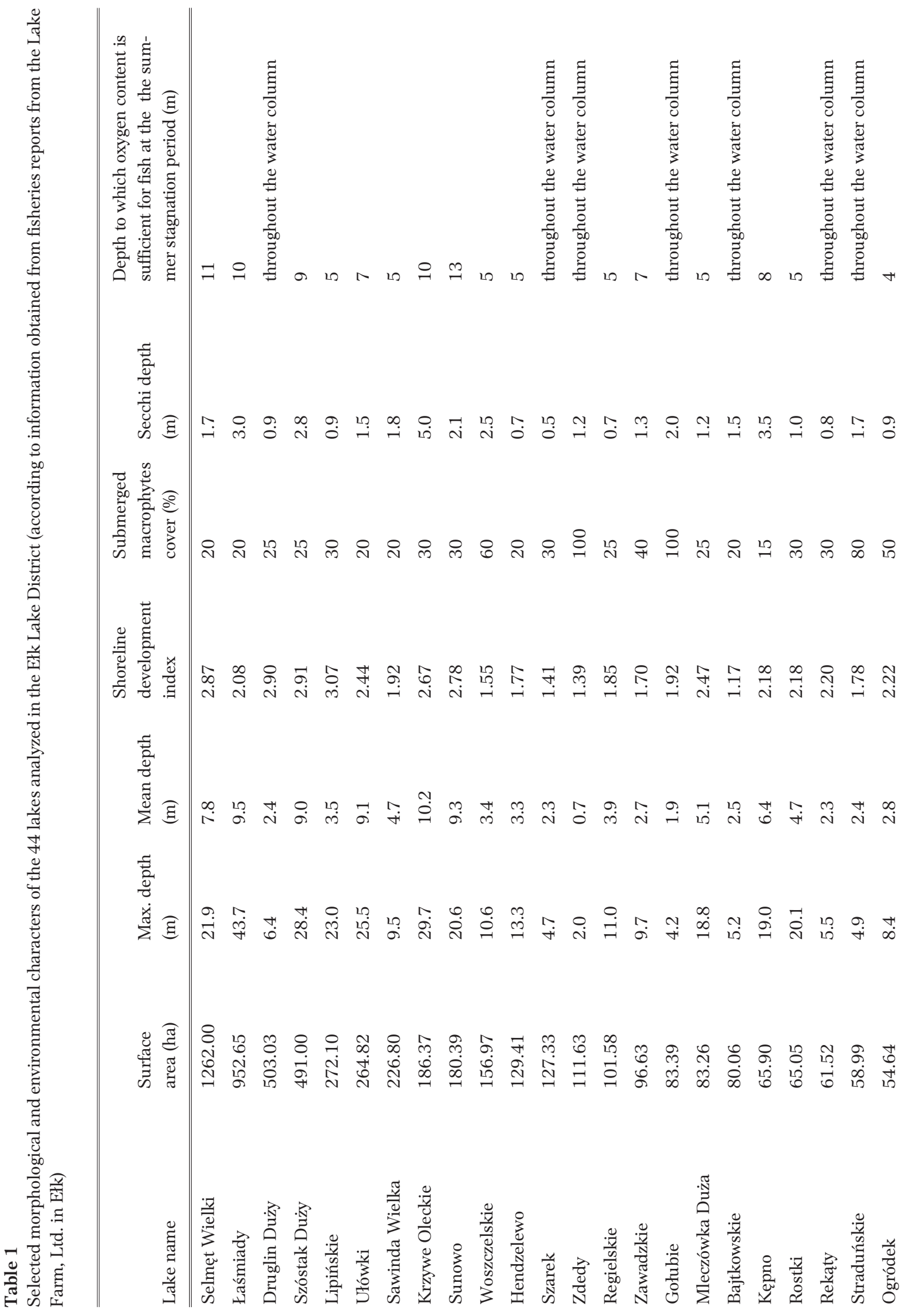




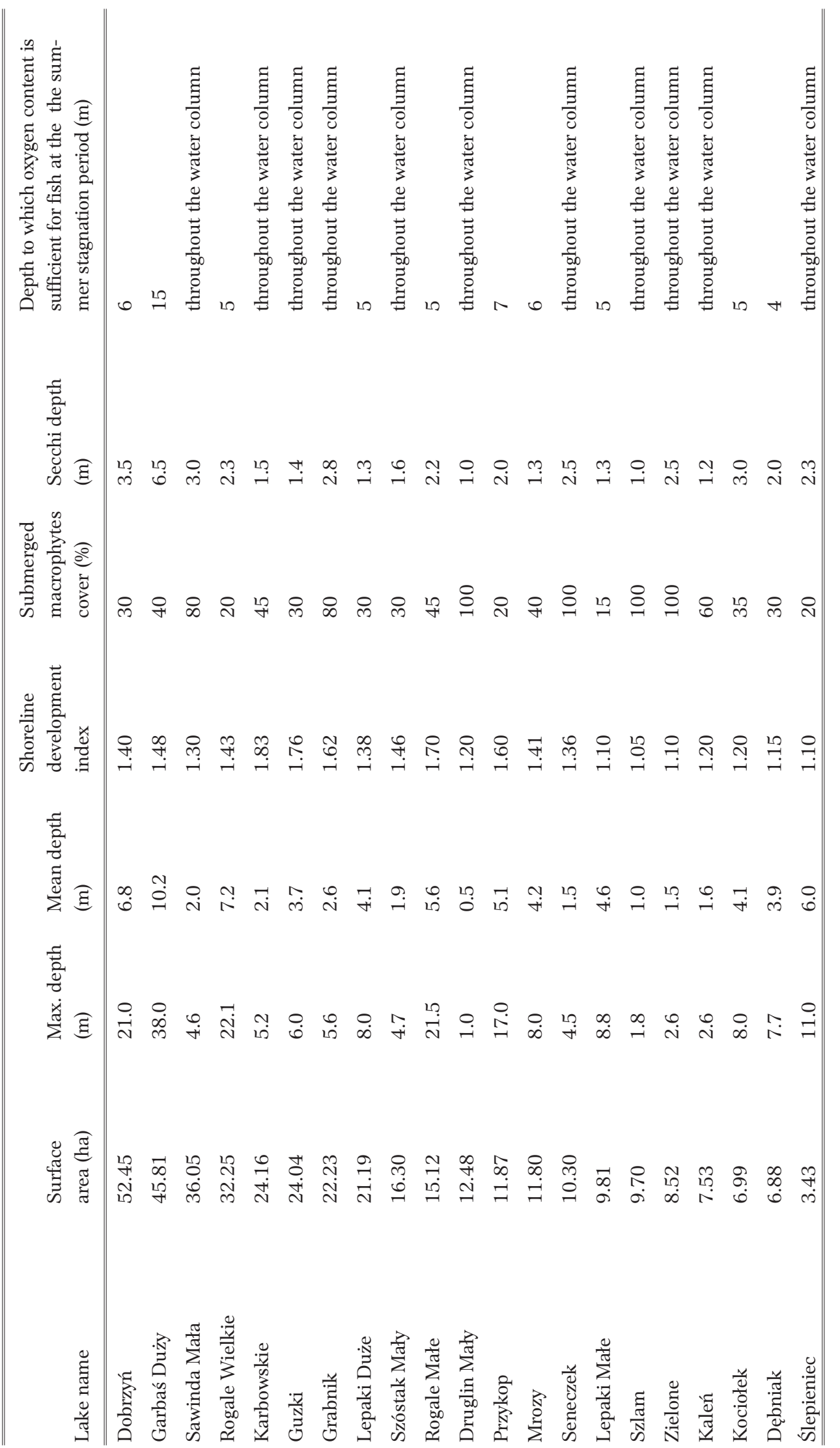




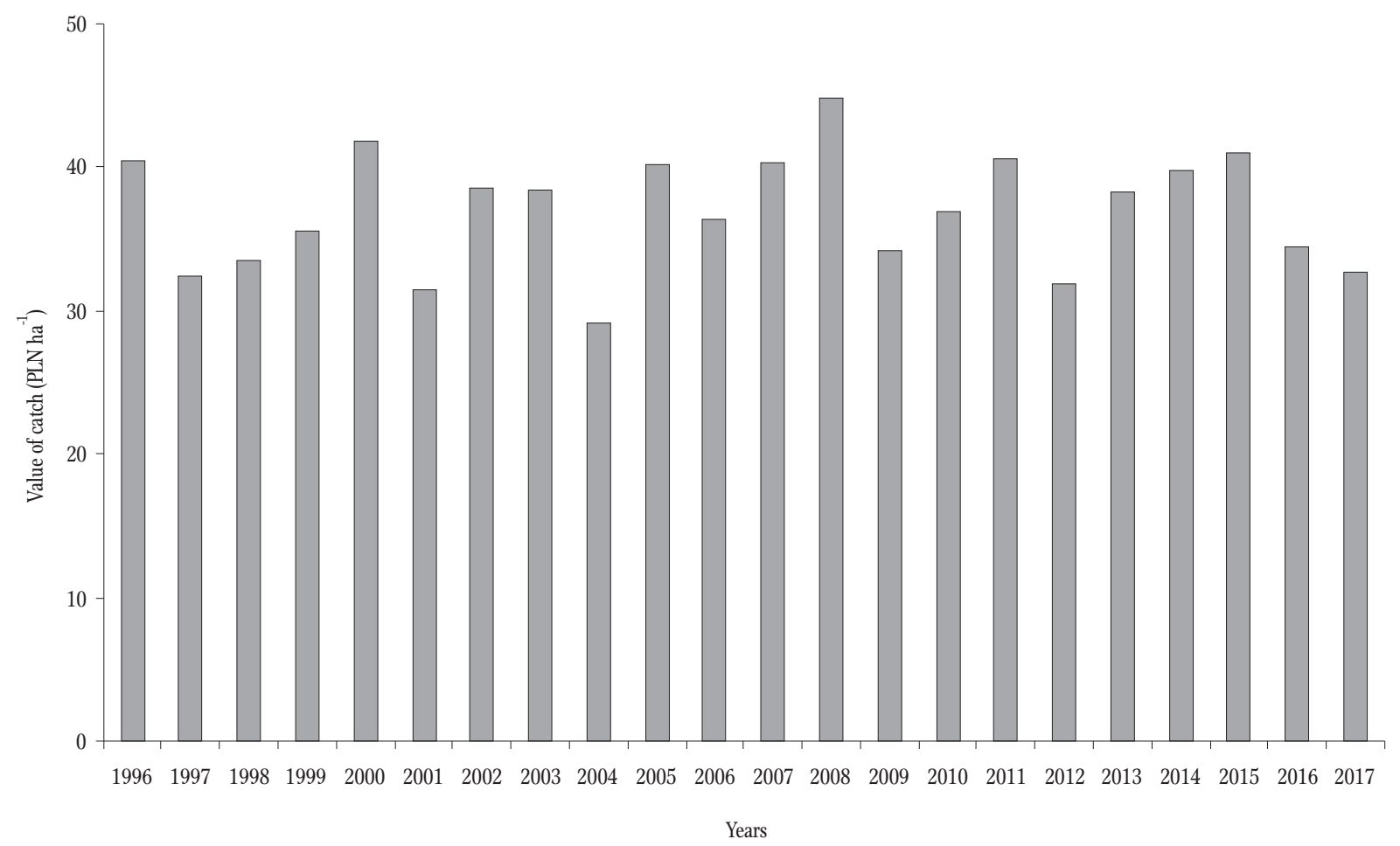

Figure 2. Changes in the value of pike catches in the lakes analyzed in the Ełk Lake District.

exposure to external factors such as temperature and insolation. Access to optimal spawning grounds and later fry migration was essential as was the substrate on which spawn was deposited (oxygenation, vegetation, low levels of suspended matter) and the rate of water exchange, which impact egg and larval development. Although the parameters analyzed in this study were not always identical to those Larsson et al. (2015) studied, they were similar. It should be emphasized that the parameters were analyzed not only with regard to their impact on pike spawning but also to the environmental requirements of this species.

The value of catches in the 1996-2017 period was stable, but some fluctuation was noted (Fig. 2). Mean annual catches were approximately 17.2 tons and $2.9 \mathrm{~kg} \mathrm{ha}^{-1}$ at a value of approximately 222,000 PLN and 36.9 PLN ha ${ }^{-1}$ (Table 2). The minimum size and value of pike catches (approximately 13.6 tons, $2.3 \mathrm{~kg} \mathrm{ha}^{-1}, 175,000$ PLN and 29.2 PLN ha ${ }^{-1}$ ) was noted in 2004, while the maximum (approximately 20.8 tons, $3.5 \mathrm{~kg} \mathrm{ha}^{-1}, 269,000$ PLN and 44.8 PLN ha $^{-1}$ ) was in 2008 (Fig. 2). In the 1998-2005 period, the annual mean value of catches of commercial pike in the lakes analyzed was approximately 29.4 PLN $\mathrm{ha}^{-1}$, and the yield was approximately $2.8 \mathrm{~kg} \mathrm{ha}^{-1}$ (Mickiewicz 2010). The catch yield for the period studied reported in Mickiewicz (2010) was nearly the same as that in the current study, but the value of these catches was lower because of the lower pike price in the period analyzed (Mickiewicz 2010). In the 2009-2014 period, the national annual mean of commercial pike catches in lakes was approximately $1.0 \mathrm{~kg} \mathrm{ha}^{-1}$ (Wołos et al. 2015), while the yield of commercial pike catches in the combined waters of lakes, rivers, and dam reservoirs was $0.6 \mathrm{~kg} \mathrm{ha}^{-1}$ in 2016. This was because only recreational fisheries of this species were conducted in most of these waters; however, the 2015 yield of anglers' catches was estimated to be close to $1.4 \mathrm{~kg} \mathrm{ha}^{-1}$ (Wołos et al. 2018).

The overall value of pike stocking increased, but fluctuations prevented determining a statistically significant trend line (Fig. 3). The mean annual value in the 1996-2017 period was approximately 68,000 PLN and more than $11 \mathrm{PLN} \mathrm{ha}^{-1}$ (Table 2). The 


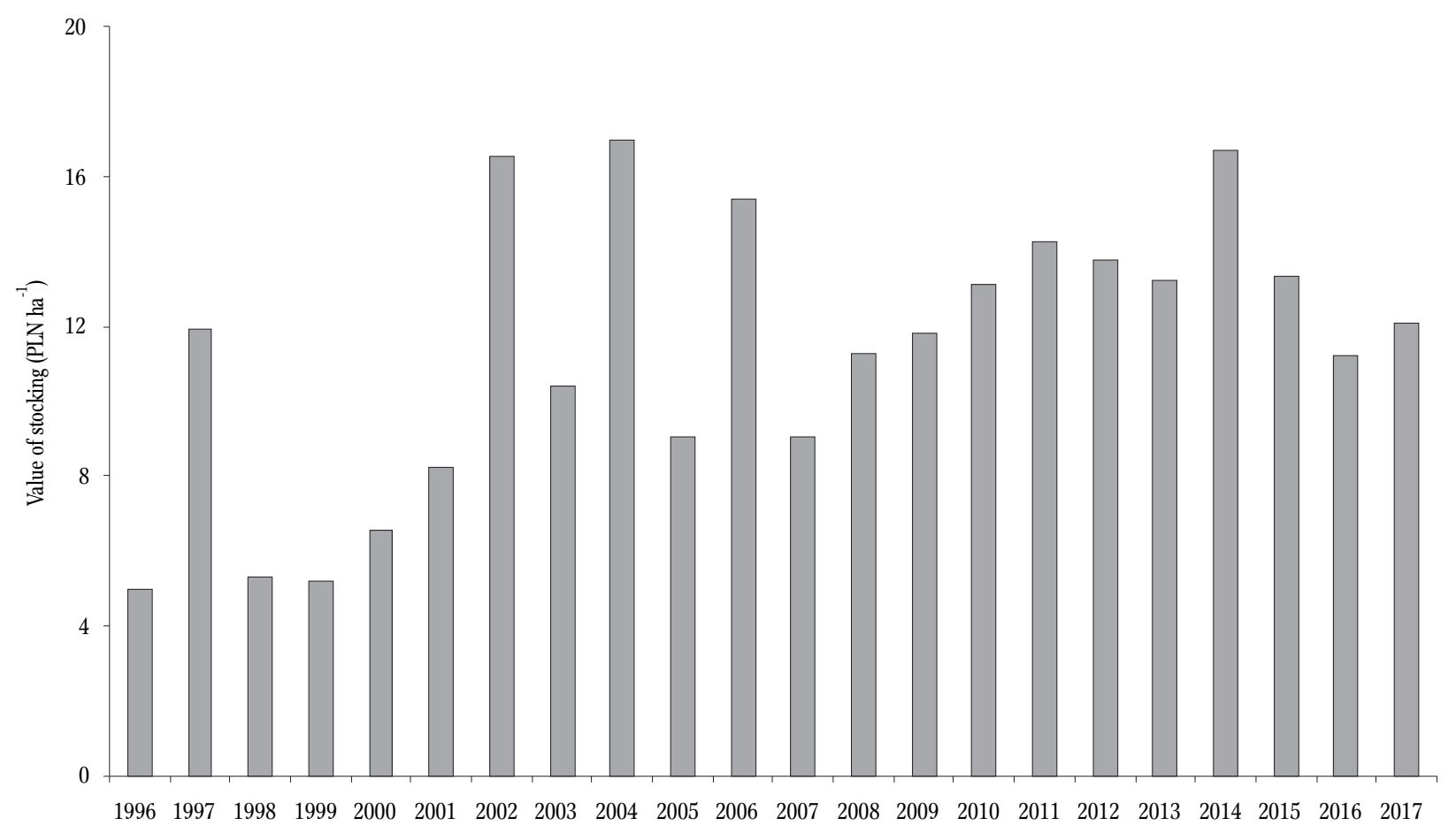

Years

Figure 3. Changes in the value of pike stocking in the lakes analyzed in the Ełk Lake District.

minimum values $\left(30,000 \mathrm{PLN}\right.$ and $\left.5 \mathrm{PLN} \mathrm{ha}^{-1}\right)$ were noted in 1996, while maximum values $(102,000$ PLN and 17 PLN ha $^{-1}$ ) were noted in 2004 (Fig. 3). Stocking based on foraging pike hatchlings obtained from hatcheries, and additional stocking with summer fry (although only twice during the period analyzed), and fall fry that was reared in earthen ponds along with foraging hatchlings. A mean of 2.85 million foraging hatchlings and $285 \mathrm{~kg}$ fall fry were released into the lakes (Table 2 ).

In the 2009-2014 period, the mean annual value of pike stocking nationally was approximately 16 PLN ha $^{-1}$ (Mickiewicz 2015). This was slightly higher than that for the lakes analyzed in the present study, while in the 2009-2014 period the value of stocking was at a level that did not differ much from that performed nationally (Fig. 3). In the 2006-2015 period the combined annual mean value of pike stocking in lakes, rivers, and dam reservoirs was 19.4 PLN ha ${ }^{-1}$ (Mickiewicz and Trella 2017).

The mean value of the three-year annual pike catches that were used to calculate the economic effectiveness of stocking was approximately 37.4 PLN ha ${ }^{-1}$, and this index was in excess of 3.9 PLN of catches per 1 PLN of stocking (Table 2). Generally, this index decreased (Fig. 4). Presumably, the value of this was actually higher since pike populations are not only exploited by commercial fishers but also by great cormorants, recreational fishers, and poachers to a very high degree. Every year, at least 4,000 great cormorants live in scattered colonies throughout the area of the lakes analyzed, and in the 1998-2005 period, only 110 recreational fishers surveyed reported mean annual pike catches exceeding 1 ton (Mickiewicz 2010).

Previous studies of the effectiveness of stocking lakes exploited by the LFE indicated that the annual mean economic effectiveness of pike stocking in the 1998-2005 period was close to 5.3 PLN of catches per 1 PLN of stocking (Mickiewicz 2010). It must be borne in mind that these figures refer to the value of recreational fishing catches and were calculated using different methodology (the value of stocking in a given year was referenced to the value of 
Table 2

Mean annual size and value of the parameters analyzed and indexes characterizing pike management in the 44 lakes analyzed in the 1996-2017 period

\begin{tabular}{|c|c|c|c|}
\hline Parameter & Mean annual & $\mathrm{V} \%$ & $\mathrm{SD}$ \\
\hline \multicolumn{4}{|l|}{ Catch parameters and indexes } \\
\hline Weight (kg) & 17,184 & 10.51 & $1,804.46$ \\
\hline Yield $\left(\mathrm{kg} \mathrm{ha}^{-1}\right)$ & 2.86 & 10.51 & 0.30 \\
\hline Value $^{1}$ (PLN) & 221,841 & 10.51 & $23,295.53$ \\
\hline Value (PLN ha ${ }^{-1}$ ) & 36.94 & 10.51 & 3.88 \\
\hline \multicolumn{4}{|l|}{ Stocking parameters and indexes } \\
\hline Quantity of foraging hatchlings (thou. ind.) & 2,847 & 46.26 & $1,259.62$ \\
\hline Quantity of summer fry (thou. ind.) & 3.00 & 322.39 & 9.18 \\
\hline Quantity fall fry $(\mathrm{kg})$ & 285 & 199.10 & 550.30 \\
\hline Total value $^{2}$ (PLN) & 6,7947 & 37.59 & $24,681.91$ \\
\hline Total value (PLN ha ${ }^{-1}$ ) & 11.35 & 37.59 & 4.11 \\
\hline \multicolumn{4}{|l|}{ Effectiveness parameters and indexes } \\
\hline Value of stocking (PLN ha $\left.{ }^{-1}\right)$ & 11.35 & 37.59 & 4.11 \\
\hline Mean annual value of average three-year catches (PLN ha ${ }^{-1}$ ) & 37.36 & 4.11 & 1.54 \\
\hline $\begin{array}{l}\text { Stocking effectiveness in the second year after stocking } \\
\text { (PLN of catches per } 1 \text { PLN of stocking }{ }^{-1} \text { ) }\end{array}$ & 3.94 & 41.74 & 1.65 \\
\hline
\end{tabular}

${ }^{1}$ according to the mean wholesale price for commercial pike in 2017 set by entities authorized to exploit fisheries in fisheries district waters (Mickiewicz 2018)

${ }^{2}$ according to mean prices for different forms of pike stocking material in 2017 used by entities authorized to exploit fisheries in fisheries district waters (Mickiewicz 2018)

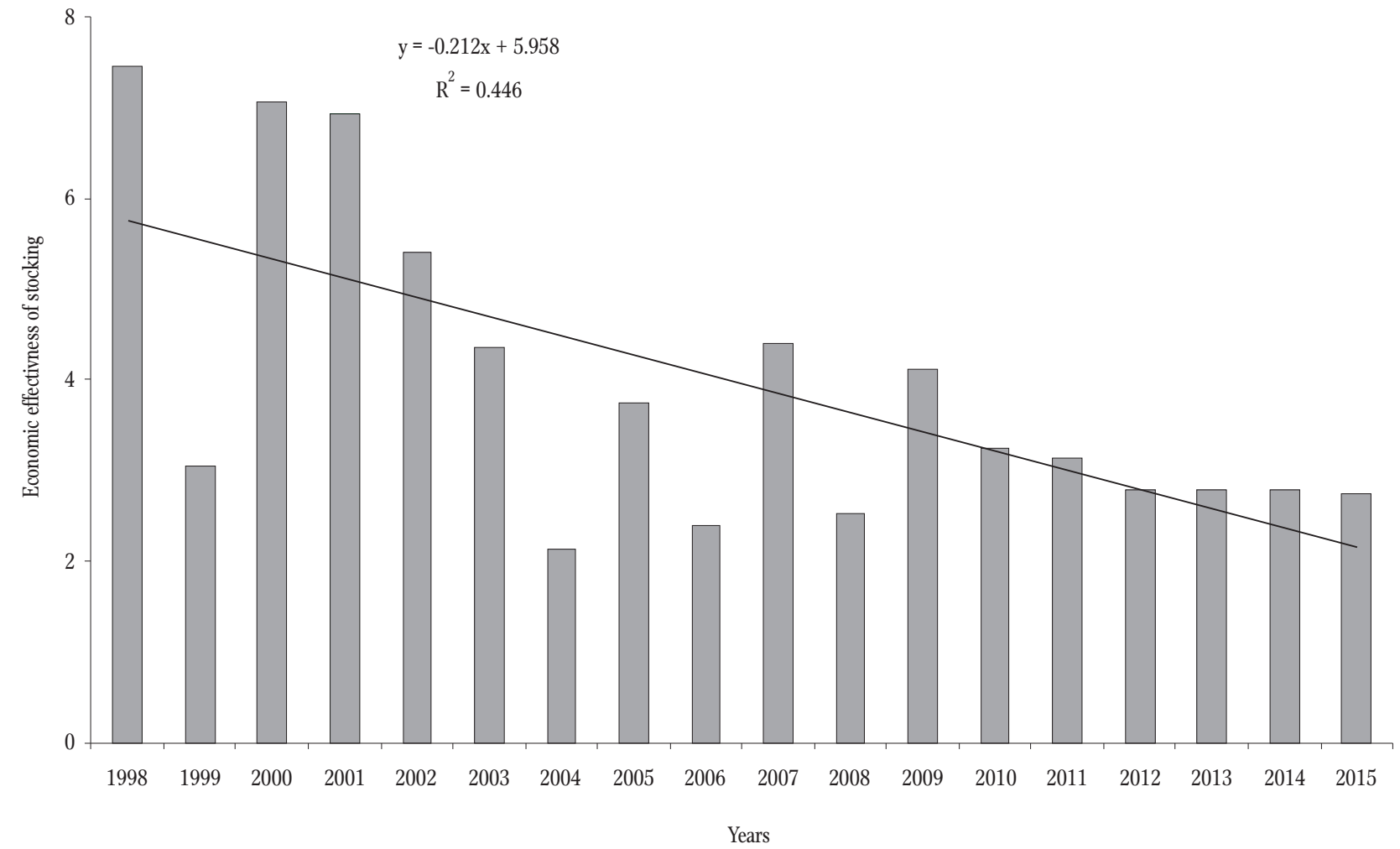

Figure 4. Changes in the economic index of the effectiveness of pike stocking (PLN of catches per 1 PLN of stocking ${ }^{-1}$ ) in the lakes analyzed in the Ełk Lake District. 
commercial and recreational catches in the same year). This same method was applied to calculate the stocking effectiveness in lakes nationally in the 1995-2007 period, but it was not possible to include the value of recreational fishing catches. In this case, the value of the index was approximately 1.3 PLN of catches per 1 PLN of stocking (Mickiewicz 2013); thus, the index was substantially lower than that calculated for the lakes analyzed. Several factors were likely responsible for such a high stocking effectiveness index in the lakes analyzed. These must have included the state of the ecosystems and the natural conditions of the lakes that were stocked that were either optimal or at least sufficient for the occurrence of strong pike populations. The quality of the stocking material used and the care taken when performing stocking must have been significant. The effectiveness of the catches (the knowledge of the fishers, the use of appropriate fishing gears, the season in which and the time when the catches were conducted) and their intensity played important roles. According to information obtained from the LFE, in 2017 the total catches of fish were $8,382 \mathrm{~kg}$ fisher $^{-1}$, the share of fishers in relation to the number of employees was $58.3 \%$, the lake surface area per fisher was $858 \mathrm{ha}$, and the number of lakes per fisher was 6.3. The same indexes nationally for lake fisheries management were $5,138 \mathrm{~kg}, 33.2 \%, 761 \mathrm{ha}$, and 8.9 lakes, respectively (Wołos et al. 2018).

Environmental conditions that were at least generally conducive for the occurrence of pike had an impact on the high stocking effectiveness of this species in the lakes analyzed. The effects of natural spawning cannot be ignored, but to what degree did it have an impact on the catches? Unfortunately, determining this would require conducting highly specialist, long-term, expensive studies that included all the lakes (e.g., mass tagging of stocking material). There are calls to base pike management on natural spawning (Czarkowski and Kapusta 2016, Arlinghaus 2018), but these are often based on the assumption that pike are caught only recreationally and preferably with the catch and release method or with diligently obeyed small size limits. Globally, $70 \%$ of stocking has been unable to stabilize the state of pike populations and increased catches, and hatchlings are unjustifiably stocked into waters in which there are sufficient levels of natural spawning (Arlinghaus et al. 2015, Arlinghaus 2017). This perspective is an optimistic one for managers of commercial and recreational fisheries who stand to profit without expenditures on stocking. Consumers who do not fish also have a right to pike catches, and this is important in regions that are popular among tourists, such as the Ełk Lake District; visitors mention the availability of fresh fish as one of the most important attractions in the area (Czarkowski and Stabiński 2015). In Poland, pike is considered to be one of the most delicious fish. Thus, commercial catches of this species are justified from a socio-cultural perspective.

One must also pose the question of whether natural spawning is sufficient. The answer to this question is probably not always bearing in mind the stability of the catches in the analyzed lakes. It is likely that without stocking these catches would fluctuate significantly along with varied spawning success. With climate change on global (Seggel et al. 2016) and regional scales and annual weather fluctuations, presumably the success of natural spawning in the period analyzed would be highly varied. Relying only on natural spawning could be disastrous. Despite successful natural spawning, pike populations could decline from deteriorating optimal environmental conditions caused by, inter alia, anthropogenic factors or long-term climate change (Larsson et al. 2015). Thus, there are not just economic and socio-cultural justifications for pike stocking, but also ecological ones.

It is controversial to argue that applying just methods such as catch and release with pike is sufficient to maintain stable, abundant populations even assuming that this species is highly resistant to stress and injury and the mortality of released fish is low (Hühn and Arlinghaus 2011). Since the principles of catch and release fishing are relatively new to the average Polish recreational fisher, even if there were applied, the mortality of inappropriately released fish would likely be very high (Trella and Wołos 2014, Trella 2018). Mortality increases 
depending on the type of bait used (Stålhammar et al. 2014), and even fish that are released correctly are exposed to stress that not only negatively affects their health but also their behavior, which can be particularly significant when these fish spawn (Stålhammar et al. 2012). Therefore, if pike catches are to be maintained at a high, stable level, it it preferable not to rely just on natural spawning or new methods of population management, but, above all else, to conduct stocking. The current results indicate the economic effectiveness of stocking, which is all the more reason to continue this practice.

In conclusion, if catches of pike in the analyzed lakes are to be maintained at a stable, high level, then stocking must be continued. The most economically and ecologically (maintaining pike that retain local characteristic and are genetically appropriate for given local populations (Berggren et al. 2016)) rational way to do this is to obtain stocking material from spawners that are caught locally, which ensures adequate stocking regardless of the possible outcome of natural spawning.

Acknowledgments. The authors would like to thank Andrzej Abramczyk, the director of Lake Fisheries Enterprise Ltd. in Ełk for providing the materials used in the study and for his many years of friendly cooperation.

Author contributions. M.M. suggested the topic, designed the study and corrected the paper. M.M. and M.T. collected data, analyzed the data, wrote the paper and performed the statistical analysis. M.T. prepared figures and map, conducted the review of the literature and follow up the process of the publication.

\section{References}

Arlinghaus R. 2017 - Nachhaltiges Management von Angelgewässern: ein Praxisleitfaden - Berichte des IGB, Heft 30.http://www.ifishman.de/publikationen /einzelansicht/555-nachhalitiges-management-von-ang elgewaessern-einpraxisleitfaden/

Arlinghaus R. 2018 - Stocking - ten procedural principles In: Pro-environmental activities in sustainable fisheries management (Ed.) A. Wołos, Wyd. IRS, Olsztyn: 61-68 (in Polish).
Arlinghaus R., Bork M., Fladung E. 2008 - Understanding the heterogeneity of recreational anglers across an urban-rural gradient in a metropolitan area (Berlin, Germany), with implications for fisheries management Fish. Res. 92: 53-62.

Arlinghaus R., Cyrus E.M., Eschbach E., Fujitani M., Hühn D., Johnston F., Pagel T., Riepe C. 2015 - Hand in Hand für eine nachhaltige Angelfischerei: Ergebnisse und Empfehlungen aus fünf Jahren praxisorientierter Forschung zu Fischbesatz und seinen Alternativen - Berichte des IGB, Heft 28. http://besatz-fisch.de/images/tories/Papers/Papers_2015/ igb_bericht_28-2015-final-neu.pdf

Berggren H., Nordahl O., Tibblin P., Larsson P., Forsman A. 2016 - Testing for local adaptation to spawning habitat in sympatric subpopulations of pike by reciprocal translocation of embryos - PloS One, 11(5): e0154488.

Bnińska M., Wołos A. 2001 - Management of selected Polish commercial and recreational lake fisheries activities Fisheries Manag. Ecol. 8: 333-343.

Czarkowski T.K., Stabiński R. 2015 - Characteristics, preferences, and opinions of fish consumers who buy directly from fisheries enterprises - Komun. Ryb. 1: 1-6 (in Polish).

Czarkowski T.K., Kapusta A. 2016 - Review of problems linked with managing pike (Esox lucius L.) populations with a particular focus on catching spawners - Komun. Ryb. 3: 13-19 (in Polish).

Guillerault N., Loot G., Blanchet S., Santoul F. 2018 Catch-related and genetic outcome of adult northern pike Esox lucius stocking in a large river system - J. Fish Biol. 93: 1107-1112.

Hühn D., Arlinghaus R. 2011 - Determinants of hooking mortality in freshwater recreational fisheries: a quantitative meta-analysis - In: The Angler in the Environment: Social, Economic, Biological, and Ethical Dimensions (Eds) T.D Beard Jr., R. Arlinghaus, S.G. Sutton, Proceedings of the Fifth World Recreational Fishing Conference, Symposium 75. Bethesda, Maryland, American Fisheries Society: 141-170.

Hühn D., Lübke K., Skov C., Arlinghaus R. 2014 - Natural recruitment, density-dependent juvenile survival, and the potential for additive effects of stock enhancement: an experimental evaluation of stocking northern pike (Esox lucius) fry - Can. J. Fish. Aquat. Sci. 71: 1508-1519.

Krzywosz T., Szymkiewicz M., Traczuk P. 2009 - The role of legally protected animals in the fisheries of the Warmia and Mazury Voivodeship - In: Diagnosing the current status and perspectives of developing inland fisheries in the Warmia and Mazury Voivodeship (Ed.) A. Wołos, Wyd. IRS, Olsztyn: 163-178 (in Polish).

Larsson P., Tibblin P., Koch-Schmidt P., Engstedt O., Nilsson J., Nordahl O., Forsman A. 2015 - Ecology, evolution, and management strategies of northern pike populations in the Baltic Sea - Ambio 44 (Suppl. 3): 451-461. 
Mann R.H.K. 1996 - Fisheries and economics - In: Pike. Fish and Fisheries Series, 19, (Ed.) J.F. Craig, Springer, Dordrecht: 219-241.

Mickiewicz M. 2010 - Economic analysis of the effectiveness of stocking lakes exploited by Lake Farm Ltd. in Ełk Komun. Ryb. 4: 5-12 (in Polish).

Mickiewicz M. 2012 - Value and structure of fish catches and stocking intensity in lake enterprises before and after fisheries ownership transfer in Poland - Arch. Pol. Fish. 20: 77-83.

Mickiewicz M. 2013 - Economic effectiveness of stocking lakes in Poland - Arch. Pol. Fish. 21: 323-329.

Mickiewicz M. 2015 - Analysis of the management and economic aspects of stocking management in the 2009-2014 period - In: Exploiting fisheries resources in the 2009-2014 period. Status, changes, tendencies (Eds) M. Mickiewicz, A. Wołos, Wyd. IRS, Olsztyn: 17-24 (in Polish).

Mickiewicz M. 2016 - Ecological, economic, and social aspects of recreational fisheries management of pike, Esox lucius L. - Komun. Ryb. 3: 20-26 (in Polish).

Mickiewicz M. 2018a - Stocking Polish lakes, rivers, and dam reservoirs in terms of the ecological, socio-cultural, and economic functions of commercial and recreational fisheries management - In: Pro-environmental activities in sustainable fisheries management (Ed.) A. Wołos, Wyd. IRS, Olsztyn: 27-46. (in Polish).

Mickiewicz M. 2018b - Price of fish and stocking material used by entities authorized to exploit fisheries in 2015 and 2017 - Komun. Ryb. 2: 1-6 (in Polish).

Mickiewicz M., Trella M. 2016 - Predatory fish species in lake stocking management - In: Fish hatcheries, rearing, and stocking (Eds) Z. Zakęś, K. Demska-Zakęś, Wyd. IRS, Olsztyn: 265-276 (in Polish).

Mickiewicz M., Trella M. 2017 - Pike stocking (Esox lucius) and its effect in fisheries district waters based on the RRW-23 survey questionnaire in the 2006-2015 period - In: Fish hatcheries and diversification of aquaculture production (Eds) Z. Zakęś, K. Demska-Zakęś, Wyd. IRS, Olsztyn: 273-287 (in Polish).

Mickiewicz M., Wołos A. 2012 - Economic ranking of the importance of fish species to lake fisheries stocking management in Poland - Arch. Pol. Fish. 20: 11-18.

Margenau T.L. 1992 - Survival and cost-effectiveness of stocked fall fingerling and spring yearling muskellunge in Wisconsin - N. Am. J. Fish. Manage. 12: 484-493.

Skov C., Lousdal O., Johansen P.H., Berg S. 2003 - Piscivory of $0+$ pike (Esox lucius L.) in a small eutrophic lake and its implication for biomanipulation - Hydrobiologia 506-509: 481-487.

Skov C., Nilsson P.A. 2007 - Evaluating stocking of YOY pike Esox lucius as a tool in the restoration of shallow lakes Freshw. Biol. 52: 1834-1845.
Søndergaard M., Jeppesen E., Berg S. 1997 - Pike (Esox lucius L.) stocking as a biomanipulation tool 2. Effects on lower trophic levels in Lake Lyng, Denmark Hydrobiologia 342: 319-325.

Seggel A., De Young C., Soto D. 2016 - Climate change implications for fisheries and aquaculture. Summary of the findings of the intergovernmental panel on climate change fifth Assessment Report - FAO Fisheries and Aquaculture Circular No. C1122 FIAP/C1122 (En), Food And Agriculture Organization Of The United Nations, Rome: 54.

Stålhammar M., Linderfalk R., Brönmark C., Arlinghaus R., Nilsson P.A. 2012 - The impact of catch-and-release on the foraging behaviour of pike (Esox lucius) when released alone or into groups - Fish. Res. 125-126: 51-56.

Stålhammar M., Fränstam T., Lindström J., Höjesjö J., Arlinghaus R., Nilsson P.A. 2014 - Effects of lure type, fish size and water temperature on hooking location and bleeding in northern pike (Esox lucius) angled in the Baltic Sea - Fish. Res. 157: 164-169.

Sutela T., Korhonen P., Nyberg K. 2004 - Stocking success of newly hatched pike evaluated by radioactive strontium (85Sr) marking - J. Fish Biol. 64: 653-664.

Szczepkowski, M., Zakęś Z., Kapusta A., Szczepkowska B., Hopko M., Jarmołowicz S., Kowalska A., Kozłowski M., Partyka K., Piotrowska I., Wunderlich K. 2012 - Growth and survival in earthen ponds of different sizes of juvenile pike reared in recirculating aquaculture systems - Arch. Pol. Fish. 20: 267-274.

Szczepkowski M., Zakęś Z., Szczepkowska B., Piotrowska I., Kozłowski M., Wunderlich K., Kapusta A. 2015 - Tag retention, growth rate, and survival of juvenile pike tagged with visible implant elastomer and coded wire tags - Bulg. J. of Agric. Sci. 21 (Suppl. 1): 12-16.

Szczepkowski M., Zakęś Z., Szczepkowska B., Wunderlich K., Kozłowski M., Piotrowska I. 2016 - Differing results of pike stocking (Esox lucius) in two Masurian lakes - In: Fish hatcheries, rearing, and stocking (Eds. Z. Zakęś, K. Demska-Zakęś, Wyd. IRS, Olsztyn: 233-241 (in Polish).

Trella M., Wołos A. 2014 - Alternative models for managing recreational fishing grounds - catch and release, no kill, and upper size limits - In: Principles and determinants of the sustainable exploitation of fish resources - part II (Eds) M. Mickiewicz, A. Wołos, Wyd. IRS, Olsztyn: 53-68 (in Polish).

Trella M., Wołos A. 2015 - Pressure and recreational catches in lakes exploited by fisheries enterprises in the 2009-2013 period - In: Exploiting fisheries resources in the 2009-2014 period. State, changes, trends (Eds) M. Mickiewicz, A. Wołos, Wyd. IRS, Olsztyn: 35-45 (in Polish).

Trella M. 2018 - Recreational fisheries today - characteristics, trends, ideas, and solutions from a Polish perspective - 
In: Pro-environmental activities in sustainable fisheries management (Ed.) A. Wołos, Wyd. IRS, Olsztyn: 81-94 (in Polish).

Winfield I.J. 2015 - Eutrophication and freshwater fisheries In: Freshwater Fisheries Ecology (Ed.) J.F. Craig, John Wiley, Oxford:779-793.

Wołos A. 1991 - Anglers' opinions as to the quality of the fishing and the fishery management in selected Polish waters - In: Catch Effort Sampling Strategies. Their application in freshwater fisheries management (Ed.) I.G. Cowx, Fishing News Books: 134-142.

Wołos A. 2000 - Economic significance of recreational fisheries in entities authorized to exploit lake fisheries Arch. Pol. Fish. 8: 1:54 (in Polish with an summary in English).

Wołos A., Draszkiewicz-Mioduszewska H., Mickiewicz M. 2015 - Size and characteristics of lake fisheries production in the 2009-2014 period - In: Exploiting fisheries resources in the 2009-2014 period. State, changes, trends (Eds) M. Mickiewicz, A. Wołos, Wyd. IRS, Olsztyn: 9-16 (in Polish).

Wołos A., Draszkiewicz-Mioduszewska H., Mickiewicz M., Trella M., Czarkowski T.K. 2018 - Fisheries management in inland flowing waters in 2016. Part 1. Entities authorized to exploit fisheries, fisheries districts, commercial catches, employment, and recreational catches Komun. Ryb. 1: 7-14 (in Polish).

Wysujack K., Laude U., Anwand K., Mehner T. 2001 Stocking, population development and food composition of pike (Esox lucius) in the biomanipulated Feldberger Haussee (Germany) - implications for fisheries management - Limnologica 31: 45-51.

Zakęś Z., Szczepkowski M., Kapusta A., Rożyński M., Stawecki K., Pyka J., Szczepkowska B., Wunderlich K., Kozłowski M., Kowalska A., Hopko M. 2015 - From aquaculture to nature. Developing alternative methods for managing the fisheries of predatory lake fish (Eds) $\mathrm{Z}$. Zakęś, M. Szczepkowski, Wyd. IRS, Olsztyn: 224. 